\title{
SENI MENDIDIK ANAK 2
}

\author{
Lara Fridani
}

$\begin{array}{ll}\text { Judul } & \text { : Seni Mendidik Anak } \\ \text { Judul asli } & \text { : Fann Tarbiyah Al-Aulaad fii Al-Islam } \\ \text { Pengarang } & \text { : Syaikh Muhammad Said Mursi } \\ \text { Penrjemah } & \text { : Muhammad Muchson Anasy } \\ \text { Penyunting } & \text { :Abdurrahman Kasdi } \\ \text { Penerbit } & \text { : Dar At-tauzi wa An-Nasyr Al Islamiyah, Kairo \& Pustaka Al-Kautsar, Jakarta, 2004 } \\ \text { Tebal halaman } & ; 560 \text { halaman } \\ \text { ISBN } & : \text { 979-592-269-6 }\end{array}$

Buku Seni Mendidik Anak 2 yang ditulis oleh Syaikh Muhammad Sa'id Mursi dan diterjemahkan oleh Muhammad Muchson Anasi memberikan infromasi yang cukup spesifik dan praktis tentang pendidikan anak yang didasarkan pada ajaran Islam. Ada sejumlah buku pendidikan anak dalam Islam yang telah dipublikasikan dan baik untuk dijadikan referensi. Kelebihan buku seni mendidik anak ini adalah banyaknya refleksi yang mengingatkan pembaca untuk menjadikan Islam sebagai landasan dalam berpikir, bersikap dan beperilaku. Selain mencantumkan berbagai aturan Islam dalam mendidik anak, penulis juga memberikan analisisnya tentang perbedaan pendidikan yang seutuhnya dan yang bukan pendidikan.

Penulis memberikan contoh kehidupan dalam keluarga/rumah tangga sehari-hari yang mengandung makna mendidik dan kurang mendidik. Lebih jauh lagi penulis menguraikan manfaat praktis kegiatan mendidik anak dari berbagai sudut pandang, termasuk sudut pandang orang tua maupun anak. Penulis memberikan berbagai sudut pandang kajian pendidikan Islam dari aspek politik, sosial, ekonomi, teknologi, seksual, psikologi, jasmani, rohani, akhlak, pengetahuan dan lainnya. Gambaran tentang tauladan Rasulullah SAW dalam membelajarkan anak dari sudut pandang Islam juga diuraikan secara komprehesif. Demikian juga dengan kiat praktis bagi pendidik dalam menyusun program untuk anak, mulai dari cara meluruskan kesalahan yang dilakukan anak, menghargai anak, dan mengembangkan minat membaca pada anak.

Penuturan penulis yang berkaitan dengan peran pendidik dalam membelajar-kan anak khususnya dari kajian psikologis dan sosial adalah bagian inti yang akan saya bahas. Dalam uraiannya tentang peran pendidik khususnya orang tua, penulis menguraikan contoh dalam keluarga di masyarakat

yang menganggap bahwa peran inti orang tua sebagai pendidik adalah sebatas memberikan makanan, ,minuman, pakaian dan tempat tinggal. Bertolak belakang dengan hal tersebut, hal-hal yang berkaitan langsung dengan pendidikan tidak dianggap sebagai bagian inti dari pendidikan itu sendiri. Hal-hal yang biasa dikesampingkan antara lain adalah upaya orang tua untuk mengubah perilaku anak ke arah positif, pengawasan terhadap ucapan dan perbuatan anak yang kurang baik, membenarkan kekeliruan yang dilakukan anak, kesempatan untuk berdiskusi dengan anak, bimbingan saat menyaksikan acara televisi dan hal-hal lain yang berkaitan dengan masalah pendidikan agama dan dunia anak. Namun demikian, belum tercantum kategorisasi usia anak yang cukup rinci dalam kajian ini. Pembagian usia yang diberikan memiliki rentang yang cukup jauh sehingga menuntut pengetahuan pembaca yang awam untuk menganalisis sendiri usia perkembangan anak yang dihadapi. Beberapa contoh kasus sehari-hari juga telah diuraikan, namun kiat praktis yang diberikan masih bersifat general dan sebagian cenderung mekanis. Pemberian kiat yang praktis dan bersifat lebih konstruktif perlu ditekankan agar anak lebih inisiatif, kreatif, dan berbagai potensinya dapat berkembang lebih optimal.

Manfaat yang bisa diperoleh orang tua tentang kegiatan mendidik anak juga diuraikan dari berbagai tinjauan seperti sebagai shadaqah jariyah, perlindungan bagi diri dan keluarga dari azab, mewarnai masyarakat dengan ajaran islami yang benar, doa yang berkesinambungan dari anak yang sholeh, melindungi anak dari pemikiran yang merusak serta pengembangan pemahaman orang tua tentang bakat dan minat yang dimiliki anak. Beberapa firman Allah dan hadits dicantumkan dalam penjelasan tentang manfaat kegiatan mendidik. 
Namun demikian, contoh praktis yang dikaitkan dalam kehidupan sehari-hari sangat terbatas dideskripsikan. Penulis lebih banyak memberikan teori yang umum dan beberapa contoh yang diberikan memerlukan penyesuaian pembaca sesuai konteks masyarakat kita. Sehingga terdapat kesan bahwa contoh yang diberikan lebih terkait pada kasus yang tidak umum terjadi.

Penulis mendeskripsikan berbagai hal yang perlu ditanamkan pendidik terhadap anak beserta contoh praktisnya yaitu:

(1) mengajarkan anak untuk menghormati dan berbakti pada orang tua yaitu dengan berbicara yang sopan, tidak memotong pembicaraan, menyambut orang tua dengan senyuman, menjalankan segala permintaan orang tua serta meminta ijin saat masuk kamar orang tua;

(2) mengajar anak untuk menjalin silaturrahim, yaitu dengan cara rutin mengunjungi kerabat, membantu kerabat yang membutuhkan bantuan, ikut merasa bahagia saat kerabat mendapat kesenangan;

(3) mengajar anak untuk menghormati tetangga, yaitu dengan membantu mereka jika dibutuhkan, tidak mengganggu ketentraman mereka, ikut bahagia saat mereka senang dan ikut merasa sedih saat mereka mengalami musibah;

(4) mengajar anak menghormati guru, yaitu dengan merendahkan suara di hadapan guru dan tidak memotong pembicaraan, tidak meniru gaya guru dengan maksud menghina, meminta ijin saat masuk ruang guru, keluar kelas dan saat berbicara atau bertanya;

(5) menghargai hak-hak teman, antara lain dengan mengunjungi teman, mendamaikan teman yang bertengkar, memaafkan jika teman bersalah, menenangkan teman;

(6) mengajar anak untuk menghormati orang lanjut usia, yaitu dengan memberinya duduk di dalam kendaraan umum, tidak mentertawakan mereka, membantu menyeberang jalan;

(7) mengajar anak untuk menyayangi yang lebih muda, yaitu dengan menemaninya belajar, mengantarkan pulang saat tersesat jalan, bermain bersama mereka dengan rendah hati dan tidak sombong;

(8) mengajar anak menyayangi binatang, yaitu dengan memberikan makanan dan minuman, tidak menyakiti binatang dan menjadikan mereka sebagai mainan. Sekalipun penulis telah memberikan contoh mendidik yang variatif, namun penjelasan masih bersifat relatif umum dan teoritis. Penjelasan contoh mendidik akan lebih bermakna ketika dituangkan dalam bentuk kasus singkat dimana para pembaca diajak untuk merefleksikan pengalamannya jika menghadapi kasus yang sama.

Contoh mendidik pun memerlukan adaptasi budaya dari pembaca, sehingga lebih kontekstual. Penulis telah mengupas tentang kebutuhan anak yang harus dipenuhi dan dihargai pendidik yang mencakup hal-hal sebagai berikut : (1) kebutuhan untuk tidur (2) kebutuhan rekreasi (3) kebutuhan akan makanan yang bergizi (4) kebutuhan akan kasih sayang orang tua (5) kebutuhan untuk bermain (6) kebutuhan untuk berprestasi (7) kebutuhan akan pakaian (8) kebutuhan akan bimbingan (9) kebutuhan tempat tinggal yang layak (10) kebutuhan akan teman (11) kebutuhan akan perlindungan dari penyakit dan bencana (12) kebutuhan akan pendidikan (13) kebutuhan akan penghargaan social (14) kebutuhan akan rasa aman. Namun kebutuhan orang tua di sisi yang lain belum diuraikan.

Jika penulis dapat menjelaskan adanya kesenjangan kebutuhan antara kedua belah pihak yaitu pendidik dan yang dididik, tentu pembaca memiliki kesempatan untuk berintrospeksi tentang hal ini dan memungkinkan adaya upaya meminimalisir adanya kesenjangan tersebut. Perbedaan harapan antara pendidik dan anak yang merupakan salah satu penyebab adanya masalah dalam proses pendidikan anak. Pendidik diharapkan menyempatkan diri mengintrospeksi berbagai hal tentang dirinya , belajar mengenali dirinya, sehingga memberikan kontribusi dalam menerapkan strategi mendidik untuk anak.

Pendidik yang intens melakukan instrospeksi diri diharapkan dapat mengetahui tantangan yang mereka hadapi dalam mendidik anak dan melakukan "brainstorming" tentang cara positif dalam menghadapi suatu stuasi/kondisi tertentu yang penuh tantangan saat berhadapan dengan anak. Pendidik perlu menyadari kelemahan dan kekuatan yang dimilikinya dan terus mengeksplor kecerdasan dirinya, terutama kecerdasan dalam memahami agama yang menjadikan landasan bagi kecerdasan lainnya (intelektual, bahasa, social-emosi, moral dan sebagainya). Pendidik yang cerdas adalah mereka yang berupaya untuk memiliki aqidah yang selamat, ibadah yang benar, fisik yang kuat, akhlaq yang kuat, pemikiran intelektual yang matang, tertib dan rapi dalam segala urusan, memanfaatkan waktu dengan baik, mengenali, mmotivasi, mengelola emosi diri dan

Perspektif Ilmu Pendidikan - Vol. 13 Th. VII April 2006 
emosi anak, serta membina hubungan yang positif dengan anak maupun orang dewasa lainnya. Penjelasan penulis tentang sifat terpenting yang perlu dimiliki orang tua maupun pendidik di sekolah dapat dijadikan bahan refleksi diri bagi kita sebagai pendidik agar berhasil meningkatkan potensi anak.

Dalam uraiannya penulis berpendapat bahwa (1) pendidik harus menjadi teladan dalam berperilaku, berpakaian, berbisara, beribadah, berakhlak, dan beretika. Dengan landasan sifat tersebut diharapkan sifat-sifat mulia lainnya akan terbentuk. Secara garis besar seluruh pola hidup guru bias dijadikan teladan oleh siapa saja (2) pendidik harus mempunyai hubungan yang baik dengan Pencipta yaitu Allah SWT, sehingga Allah akan memberkahi mereka (3) Pendidik harus berjiwa besar dan bercita-cita tinggi yang berarti yang berarti mereka memiliki motivasi yang kuat dan tidak mudah putus asa (4) Pendidik harus menyayangi, mencintai dan dicintai, antara lain dngan berada dekat bersama dengan anak, sederhana dan rendah hati dalam berbicara serta bemain dan bergurau bersama anak (5) mengendalikan diri, diantaranya tidak memelihara kemarahan dan menghukum anak secara emosional (6) banyak membaca untuk memperluas pengetahuan khususnya tentang hal-hal yang berkaitan dengan pendidikan anak sehingga memiliki kemampuan untuk menyelami dunia anak (7) mampu berkomunikasi secara efektif dengan (8) memiliki tujuan yang jelas dalam membelajarkan anak sehingga dapat memberikan hasil yang positif bagi anak.

Uraian penulis akan lebih lengkap jika pembaca kembali diajak untuk melakukan analisis tentang pengalaman mendidik anak yang telah mereka lakukan. Pembaca perlu disarankan untuk belajar mengamati kebutuhan anak dan berupaya memahami perkembangan anak baik secara khronologis maupun mental. Ketika pendidik tidak memahami karakteristik dan kebutuhan anak, maka pendidik merasa (1) berbuat hal positif dalam berbagai aspek perkembangan anak (2) pendidik menjadi kurang sensitive dan berharap banyak dari anak (3) gagasan dan "niat baik anak" di label buruk dan lainnya. Hal ini tentu saja tidak meningkatkan kualitas kita sebagai pendidik dan memberikan dampak yang tidak baik bagi perkembangan anak. Pembaca juga perlu diingatkan bahwa untuk menjadi pendidik yang berkualitas, maka peran berikut perlu dihindari : (1) pelabel negative anak (2) penginterogasi aktif terhadap anak (3) penasehat yang tidak mau dinasehati (4) pencari solusi sepihak (5) pelaku pelecehan (fisik, psikis, seksual, maupun penolakan) pada anak.

Buku seni mendidik anak 2 merupakan referensi yang sangat bermanfaat bagi pendidik dalam mengkaji berbagai cara mendidik dengan menggunakan seni dan berlandaskan ajaran Islam. Kesimpulan yang dapat ditambahkan dalam bku ini adalah bahwa dalam mendidik anak ada beberapa hal yang perlu dilakukan oleh pendidik, antara lain : (1) keterlibatan dengan anak secara kualitas dan kuantitas (2) mencintai anak tanpa syarat yang disesuaikan dengan ajaran agama Islam (3) memberikan lingkungan yang aman, menarik dan meminimalkan kompetisi (bagi anak usia dini) (4) menghargai anak (5) menggunakan disiplin sesuai dengan tahapan perkembangan anak (6) menggunakan bahasa yang positif dan konstruktif saat berkomunikasi (7) menetapkan batasan dan memberikan pilihan sesuai dengan landasan agama serta (8) memiliki rasa humor dan lainnya. Dengan demikian dalam mendidik anak, pendidik yang berkualitas tentu tidak memiliki pemikiran yang sempit, dimana mereka merasa harus selalu mengontrol anak, harus sempurna mendidik anak, ataupun sebaliknya, yaitu harus selalu menuruti kemauan anak dan harus selalu melindungi anak. Pendidik sebagai pribadi dewasa belum tentu selalu lebih tahu dan lebih benar daripada anak. Pendidik perlu menghargai anak dengan segala keunikannya dan dengan berbagai tahapan perkembangan yang akan dilaluinya. Sebagai pendidik kita berharap agar anak-anak kita dapat terus maju dan berkembang segala potensinya berlandaskan ajaran agama.

\section{KETERANGAN PENULIS}

Lara Fridany, S.Psi, M.Psych (Edu \& Dev), lahir di Jakarta pada tahun 1973. Saat ini bekerja sebagai staf pengajar di Program Studi Pendidikan Anak Usia Dini FIP UNJ. Selain itu juga aktif sebagai Konsultan Pusat Intervensi Dini Sega, Psikolog Multipro Bogor, trainer bidang pendidikan dan perkembanganm, serta aktif menulis rubrik keluarga di majalah Islam Sabili. Menyelesaikan pendidikan terakhirnya di Monash University Melbourne Australia dalam bidang Psikologi (pendidikan dan perkembangan), kemudian tahun 2001-2003 mengambil spesialisasi Anak dengan masalah perkembangan (Autisme dan hiperaktif). 